\title{
SARS-COV-2 MUTATIONS AND VARIATIONS AND HOW COVID-19 VACCINES WORK AGAINST THE VARIANTS
}

\author{
ELŻBIETA NOWAKOWSKA ${ }^{1 *}$, JOANNA MICHALSKA ${ }^{3}$, SYLWIA SULIMIERA MICHALAK $^{1}$, \\ and ANNA PACZKOWSKA ${ }^{2}$
}

\author{
${ }^{1}$ Department of Pharmacology and Toxicology Institute of Health Sciences, Collegium Medicum, \\ University of Zielona Góra, Zielona Góra, Poland \\ ${ }^{2}$ Department of Pharmacoeconomics and Social Pharmacy, \\ Poznań University of Medical Sciences, Poznań, Poland \\ ${ }^{3}$ Collegium Medicum University of Zielona Góra, Zielona Góra, Poland
}

\begin{abstract}
SARS-CoV-2, the virus that causes COVID-19, has had a major impact on human health globally; infecting a large number of people and resulting in increased mortality. The WHO has received many reports of SARS-CoV-2 mutations and variants. The best-known variants are the British, South African, and Brazilian variants, which differ in the genetic record but share the N501Y mutation, which exists in the receptor-binding domain, and is critical for binding to the human ACE2 receptor (angiotensin-converting enzyme 2). So far, mRNA (Pfizer, Moderna) and vector (Astra Zeneca, Johnson \& Johnson) vaccines have been used against the SARS-CoV-2 virus. Others are undergoing diagnostic tests. However, further research is needed to show how the respective vaccines deal with the identified mutations and the whole range of SARS-CoV-2 variants. A systematic review including the current evidence related to different variants of SARS-CoV-2 and COVID-19 vaccines was conducted through a systemic search utilizing the keywords in the online databases including Scopus, PubMed, and Web of Science; we retrieved all related papers and reports published in English from 2019 to 2021.
\end{abstract}

Keywords: SARS-CoV-2 mutation, emerging variants, vaccines for COVID-19.

The COVID-19 pandemic caused by SARS-CoV-2 is still spreading all over the world, posing a threat to human health and life. Following the first and second waves of infections, in 2021 we are entering the third phase, more dangerous due to the emerging SARS-CoV-2 mutations and variants. In Poland, according to data provided by the Ministry of Health (as of 11th May 2021), a 7-day average for new infections amounted to over 9.4 thousand.

On 11th May 2021, the Ministry of Health informed about 3098 thousand new coronavirus infections. The number of all confirmed cases of coronavirus in the world has exceeded 160 million. So far, in the COVID-19 the death toll stands at over 3 million people.

The emerging mutations and new variants of SARS-CoV-2 raise big concerns among virologists and clinicians. The virus may spread quicker and demonstrate higher contagiousness which will lead to a greater number of deaths.
In Europe, the virus reproduction coefficient (reproductive ratio $\mathrm{R}$ - the average number of people to whom one person will transmit the virus) exceeds 1 , which means that the pandemic is not dying out despite the restrictions and extended lockdown, as well as the commenced vaccinations (1).

SARS-CoV-2 (Severe Acute Respiratory Syndrome Coronavirus 2) is an enveloped virus belonging to the group of coronaviruses classified as Coronaviridae Nidovirales order (2) and is one of the largest RNA viruses as regards to the length of its genome. Coronaviruses belong to single-stranded RNA viruses. Their virion is composed of a capsid created by nucleocapsid proteins $(\mathrm{N})$ and an envelope composed of membrane proteins (M) and an envelope (E) that covers the spike protein (S). SARS-CoV-2 protein S composed of subunits S1 and $\mathrm{S} 2$ mediates in a virus entering the host cells, binding its receptor, angiotensin-converting enzyme 2 (ACE2), through the receptor-binding domain (RBD) at the $\mathrm{C}$ end of subunit $\mathrm{S} 1$, which results in the fusion

* Corresponding author: e-mail: elapharm@poczta.onet.pl 
of the viral envelope and host cell membrane by subunit S2 (3).

Viruses evolve as a result of new mutations (sudden, step changes in the genetic material of the virus). It has been confirmed beyond all doubts that SARS-CoV-2 is mutating (4) thus leading to the creation of new variants of the virus, and each variant may affect the transmissibility, the clinical picture of the disease, the risk of severe course of the infection, and the effectiveness of drugs or vaccines applied (5).

The genetic material of SARS-CoV-2 is nonsegmented RNA with positive polarity built of 29.903 nucleotides which code 9860 amino acids (3). SARS-CoV-2 genome codes 16 non-structural proteins needed for replication, structural proteins
(6-8) and contains approximately 30 thousand pairs of bases, which is sufficient to detect nucleotides changes in the virus genome. The changes occurring in the nucleotide sequence may lead to mutations that occur naturally and spontaneously during the replication process, and in the case of RNA viruses (including coronaviruses), the mutations are caused by polymerases errors, the enzymes responsible for replicating genetic material. Additionally, RNA viruses mutate quicker than DNA viruses (e.g. adenoviruses) because of their strong genetic variability (9).

A consequence of the changes in the virus genome may be the occurrence of new mutations, often of increased virulence (9-12).

To date, many SARS-CoV-2 mutations have been identified (13).

Table 1. SARS-CoV-2 mutations (Infographic: Mutation of SARS-CoV-2- current variants of concern (VOC), variant of interest (VOI) European Centre for Disease Prevention and Control - 6 May 2021. Own study based on (19-21).

\begin{tabular}{|c|c|c|c|c|}
\hline $\begin{array}{l}\text { Variant name: VOC } \\
\text { 202012/01, or 501Y.V1 } \\
\text { Lineage: B.1.1.7 } \\
\text { First case } \\
\text { discovered: } \\
\text { September 2020 } \\
\text { Land of first } \\
\text { discovery: United } \\
\text { Kingdom } \\
\text { First discovery in } \\
\text { EU/EEA: } \\
\text { 09 November } 2020 \\
\text { Mutations on spike } \\
\text { protein: } \\
\text { 8 spike protein, } \\
\text { 17 mutants in genome } \\
\text { Mutations on } \\
\text { receptor-binding } \\
\text { domain (RBD): } \\
\text { N501Y } \\
\text { Properties: } \\
\text { increased } \\
\text { transmissibility } \\
\text { and possibly } \\
\text { increased } \\
\text { contagiousness } \\
\text { Risks of immune } \\
\text { escape: } \\
\text { Limited escape from } \\
\text { existing neutralizing } \\
\text { antibodies, } \\
\text { convalescent plasma, } \\
\text { vaccinated serum } \\
\text { retain neutralizing } \\
\text { ability } \\
\text { Regions affected: } \\
\text { 80 countries in } \\
\text { Europe, Asia, } \\
\text { North\&South } \\
\text { America, now } \\
\text { domint in the U.S. }\end{array}$ & $\begin{array}{c}\text { Variant name: } \\
\text { 501 Y.V2 } \\
\text { Lineage: B.1.351 } \\
\text { First case } \\
\text { discovered: October } \\
\text { 2020 } \\
\text { Land of first } \\
\text { discovery: South } \\
\text { Africa } \\
\text { First discovery in } \\
\text { EU/EEA: } \\
\text { 28 December } 2020 \\
\text { Mutations on spike } \\
\text { protein: } 10 \\
\text { Mutations on RBD: } \\
\text { K417N, E484K, } \\
\text { N501Y } \\
\text { Properties: } \\
\text { increased } \\
\text { transmissibility } \\
\text { and possibly } \\
\text { decreased } \\
\text { efficacy of the } \\
\text { vaccine } \\
\text { Risks of immune } \\
\text { escape: } \\
\text { Significant decrease } \\
\text { of neutralizing ability } \\
\text { by neutralizing } \\
\text { antibodies, vaccine } \\
\text { efficacy compromised } \\
\text { Regions affected: } \\
\text { Africa, Europe, } \\
\text { Asia, Australia, etc. }\end{array}$ & $\begin{array}{c}\text { Variant name: } \\
\text { 501Y.V3 } \\
\text { Lineage: P.1 } \\
\text { First case } \\
\text { discovered: } \\
\text { December } 2020 \\
\text { Land of first } \\
\text { discovery: } \\
\text { Brazil } \\
\text { First discovery in } \\
\text { EU/EEA: } \\
\text { 12 January } 2021, \\
\text { Brazilian tourist in } \\
\text { Japan } \\
\text { Mutations on spike } \\
\text { protein: } 12 \\
\text { Mutations on RBD: } \\
\text { K417T, E484K, } \\
\text { N501Y } \\
\text { Properties: } \\
\text { no evidence } \\
\text { of increased } \\
\text { transmissibility and } \\
\text { possibly decreased } \\
\text { efficacy of the } \\
\text { vaccine } \\
\text { Risk of immune } \\
\text { escape: } \\
\text { Likely to escape; } \\
\text { further research } \\
\text { needed } \\
\text { Regions affected: } \\
\text { Brazil, Northern } \\
\text { Europe, U.S., Korea, } \\
\text { etc. }\end{array}$ & $\begin{array}{c}\text { Variant name: } \\
\text { CAL. 20C } \\
\text { Lineage: B. 1.427, } \\
\text { B.1.429 } \\
\text { First case } \\
\text { discovered: } \\
\text { July } 2020 \\
\text { Land of first } \\
\text { discovery: California } \\
\text { US } \\
\text { Mutations on spike } \\
\text { protein: } 3 \\
\text { Mutations on RBD: } \\
\text { L452R } \\
\text { Properties: } \\
\text { No evidence } \\
\text { of increased } \\
\text { transmissibility, more } \\
\text { infections } \\
\text { Risks of immune } \\
\text { escape: } \\
\text { No evidence of } \\
\text { immune escape yet } \\
\text { Regions affected: } \\
\text { Germans, Austria, } \\
\text { Denmark, Israel, } \\
\text { Britain, Singapore, } \\
\text { New Zealand etc. }\end{array}$ & $\begin{array}{c}\text { Variant name: } \\
\text { "double mutant" } \\
\text { Lineage: B.1.617 } \\
\text { First case } \\
\text { discovered: } \\
\text { October } 2020 \\
\text { Land of first } \\
\text { discovery: India } \\
\text { Mutations on spike } \\
\text { protein: } 7 \\
\text { Mutations on RBD: } \\
\text { L452R, E484Q } \\
\text { Properties: variant of } \\
\text { interest } \\
\text { Risks of immune } \\
\text { escape: E484Q lies } \\
\text { at the same location } \\
\text { as E484K, a mutation } \\
\text { that might help the } \\
\text { virus evade some } \\
\text { types of antibodies } \\
\text { Regions affected: } \\
\text { Britain, U.S., Israel }\end{array}$ \\
\hline
\end{tabular}


Most of the mutations concern protein of spikes which play a significant role in recognizing potential host cells and are recognized by the immune system. Genetics theories assume that most of the mutations should be neutral, beneficial, or detrimental to the virus (14), some do not affect the amino acids system, proteins, and do not affect the biological properties of the virus (15). Beneficial and neutral mutations are retained and therefore they occur in a given population more frequently (16). Some mutations may provide the virus with a selective advantage, i.a. easier transmission.

Natural selection promotes those mutations that increase the contagiousness of the virus but do not lead to negative health results because the infected vector does not transmit the pathogen to others. Some mutations appear spontaneously and vanish quickly, e.g. deletion of 382 nucleotides within the SARS-CoV-2 genome which was named ORF-8, does not provide the virus with a selective advantage, and as it has been established, it causes less severe symptoms of COVID-19 (17).

So far, British scientists have isolated 12000 mutations of SARS-CoV-2 after sequencing over 200 thousand virus genomes (17). They confirmed that SARS-COV-2 is subject to mutations in different parts of its non-structural proteins (NSP), especially NSP2 and NSP3, protein S (fusion protein responsible for interaction with the receptor) RNAdependent RNA polymerase (RdRp) (18) and suggest that most likely, none of them increases the virulence and contagiousness of this pathogen (11).

The mutations best known and described so far are presented in Table 1.

\section{SARS-CoV-2 variants recognized so far}

SARS-CoV-2 variants are the forms of the virus with a specific system of mutations (14), their molecular properties are deposited in the international database of the virus sequences reporting system GISAID (22). They are designated with acronyms, e.g. British -B1.1.7, South-African B1.351, known as 20H/501.Y.V2, and Brazilian B1.1.28, known as P1 (23).

Different variants of the virus emerge during a pandemic, most of which contain mutations in RBD of the spike proteins which may increase transmissibility.

According to data from the GISAID database, three major clades of SARS-CoV-2 can be identified clade $\mathrm{G}$ (variant of the spike protein S-D614G), clade $\mathrm{V}$ (a variant of the ORF3a coding protein NS3-G251), and clade S (variant ORF8-L84S) (24). Such new variants vary in origin, genetic record (13) but also have some features in common (14); they are all characterized by a specific system of sense mutations that cause singular changes in the amino acid system in virus proteins. The British, South-African and Brazilian variants have mutation N501Y (Table 1) which exists in the receptor-binding domain and has a decisive effect on binding with human ACE2 receptors (angiotensin-converting enzyme 2).

At the turn of February and March 2020, D614G mutation emerged globally in the gene coding spike protein $(25,26)$ which is responsible for the interaction between virus particles and the receptor, and plays a significant role in the process of a virus entering the host cells and causing infection $(27,28)$. Changes in spike protein S concern the exchange of aspartic acid (D) with glycerine $(G)$ in position 614 of glycoprotein $\mathrm{S}$, on which virus penetration inside the epithelial cells of respiratory tracts depends $(29,30)$.

A hypothesis has been suggested that the described change of amino acids building spike protein causes virus replication, characterizes by increased ability to infect and transmit however it does not affect the severity of the disease (5).

At present, the biggest concern is raised by mutation E484K (31) which is present in South-African and Brazilian variants, and most recently also in British variant. This mutation is likely to lead to decreased activity of antibodies towards protein $\mathrm{S}$ of the coronavirus (14). Lately, there were reported cases of re-infections with variants including E484K mutation (14). Reports published in (32) indicate that this mutation does not significantly affect the level of antibodies after application of two doses of mRNA vaccines, however, it may cause re-infections in convalescents.

English Covid Genomics consortium described a SARS-CoV-2 variant named VOC202012/01 (VOC - variant of concern, the year 2020, month 12 , variant 01), lineage - B.1.1.7, or 20B/501Y.V1) discovered in December 2020 in London, and Kent County. For scientific purposes, this variant was named VUI202012/01 (33), then it was reclassified to LZO202012/01 variant (26 December 2020) on the basis of genomic studies performed in the territory of the UK (34).

VOC-202012/01 variant has 17 different sense mutations and D614G mutation. In positions 69 and 70 in protein $S$ the lack of two amino acids was confirmed (deletion) (26). Such change of the set of amino acids in protein $\mathrm{S}$ is deemed to be one of the adaptive features of the virus. Apart from the above-mentioned deletion, there is observed a change of amino acids in position 614 , where D was replaced with G (D614G) - aspartic acid was replaced with tyrosine (35). There was also confirmed 
ORF8 Q27 mutation “stop” outside the spike protein, and the most dangerous mutation N501Y which concerns the change in protein $\mathrm{S}$ sequence present on the spike in the receptor-binding domain (RBD).

Sequencing of the genome was performed, and it was established that VOC-202012/01 variant is dominant in the UK and is responsible for $50 \%$ of all discovered cases of coronavirus infections. Currently, according to WHO, it is present in 94 states, including in Poland, and is characterized by increased transmissibility, higher reproductive number, and higher viral load. Reports of London School of Hygiene \& Tropical Medicine and Imperial College London suggest that this variant may be very deadly, which is due, among others, to N501Y mutation which causes that viral spike protein adheres more closely to the host cell receptor. Whereas there are no reports suggesting that the existing vaccines may be less efficient (36), although clinical trials performed recently by Novavax and Johnson\&Johnson show that their vaccines were less efficient in case of a high level of a virus with E484K mutation.

Recently, another highly transmissible lineage of mutation - B.1.351, also known as 501Y, was identified. V2 and it was stated that it has 9 mutations in gene $S$ (25), which leads to a change in the sequence of protein S present on the spike. This variant does not contain the deletion at 69/709 (23). There is some evidence to indicate that one of the spike protein mutations, E484 K, may affect neutralization through some polyclonal and monoclonal antibodies (37).

In August and September 2020, in Northern Ireland and Denmark a variant of SARS-CoV-2 was identified (the focus was specified as "Cluster 5") and associated with the infection of bred minks, likely to be transmitted to humans (38). This variant also has a combination of mutations, mainly with Y453 F mutation in glycoprotein $\mathrm{S}$ and 3 other mutations within glycoprotein S (del 69_70,I692V,M1229I, which is associated with easier adhesion to receptor cells' proteins in minks, but it is likely that it does not affect the adhesion to the human receptor and therefore it should not survive in the human population.

Other reports show that in the case of human infection it may affect the duration of COVID-19 and shorter immune protection (5). WHO has declared that Cluster 5 has moderately reduced sensitivity to neutralizing antibodies (39).

South-African variant B.1.351, also named 501Y. V2 because of N501Y mutation. Another name 20H/501Y.V2 (23) was identified in the Republic of South Africa at the end of December 2020, where it is the most widely spread variant (40). It is also present in $10 \mathrm{EU}$ states, including the UK, and since
January 2021 it has been present in the USA (41). It is characterized with 20 sense mutations and DG14G mutation, 9 of which lead to changes in amino acids sequences in protein $\mathrm{S}$, whereas there is no deletion $69 / 70$ in glycoprotein S. This variant may demonstrate increased transmissibility, still, there is no specific evidence that it may contribute to more severe course of COVID-19. Considering that this variant also includes E484K mutation which has a negative effect on antibodies binding and virus neutralization, the developed vaccines may be ineffective.

The Brazilian variant of B.1.1.28 (20J 501Y.V3), known as P1, was recognized at Tokyo airport at the end of 2020 in 4 people traveling from Brazil, and in January 2021 its presence was confirmed in the USA. According to WHO, it is now present in 21 states of the world. As regards mutation, this variant resembles the South-African variant. It has 17 mutations, three of which (K 417T, E484K, N501Y) concern changes in protein $\mathrm{S}$ sequence. It is suspected that it may demonstrate higher transmissibility (42).

Some research shows that the South-African and Brazilian variants which cumulate dangerous mutations - K417 and E484 may cause weaker affinity of antibodies to this virus, and cause reinfections in persons who have already undergone a COVID-19 episode (36).

British, South-African and Brazilian variants differ in mutations, but they all have N501Y mutation which leads to a change in receptor binding domain (protein $\mathrm{S}$ ) - substitution of asparagine $(\mathrm{N})$ by tyrosine (Y) at position 501 of the spike protein within the RBD domain (26) which may cause increased contagiousness, although the implications for transmission and virulence have not been sufficiently confirmed $(26,43,44)$.

A US government interagency group developed a variant classification scheme that defines three classes of SARS-CoV-2 variants (variant of interest - VOI, variant of concern - VOC, variants of high consequence-VOHC) (45).

Three variants of SARS-CoV-2 - B.1.427, B.1.429 (variants of concern - VOC), and B.1.526 (variant of interest - VOI) were discovered in the United States. At present, the variants B.1.427, B.427), named CAL.20C are dominant in California, but the B.1.526 variant is dominant in New York. The variant appears in two forms: one with the E484K spike mutation which may help the virus evade antibodies and the S477N mutation which may help the virus bind to human cells (46). Those variants differ in the system of mutations which lead to changes in different domains of the SARS-CoV-2 genome. Variants B.1.427 and B. 1429 have mutation L249R 
in receptor binding domain (also known as 20C/ L452R); the third variant B.1.526 has 10 mutations including 3 which lead to amino acids changes in protein $\mathrm{S}$ which allow the virus to interact more easily with ACE2 receptor $(45,47)$.

According to scientists of the University of California San Francisco (UCSF), CAL20C variants shall not only spread quicker, but they are also more contagious which might be due to L452R mutation which allows the virus better interaction between spike protein and the receptor on host cells surface, and that mutation is also more resistant to antibodies produced by COVID-19 vaccines $(48,49)$.

The latest SARS-CoV-2 variant dubbed B.1.617, was first found in India and then in other countries around the world. It is too early to say whether the new B.1.617 variant of the virus is responsible for the rapid increase in infections, but it is being treated as a possible cause. The Indian variants consist of three mutations on the spike protein of the virus (L452R, E484Q, D614G) (45).

E484Q is similar to E484K, a mutation seen in the South African B.1.353 variant and the Brazilian P1 variant. This variant has one specific mutation called D614G. There is evidence that variants with this mutation spread more quickly than those without this mutation (50).

On $10^{\text {th }}$ May 2021, the WHO reclassified India's coronavirus mutation as a "variant of concern" at the global level, due to new test results that confirmed the rapid spread of the virus.

So far, there is no unequivocal evidence of increased transmissibility of SARS-CoV-2 in the human population in conjunction with any genetic mutation (25) it has not been confirmed either that any of the mutations known so far affected the severity of COVID-19 symptoms, or jeopardized the efficacy of vaccines, however, considering the critical importance of mutations in the pathogenesis of SARS-CoV-2, constant molecular supervision is recommended. WHO systematically collects information on emerging new variants and assesses whether a new variant may affect the ability of virus transmissibility, the risk of severe infection, and the efficacy of vaccines administered (30).

Further research is needed to confirm transmissibility, intensification of infection, or severe course of COVID-19.

\section{Mutations vs. vaccines efficacy}

Due to the rapid spreading of the virus, the relatively high death rate caused by the virus, and no targeted treatment available, vaccinations seem to be a chance to return to normality (51). The urgent need to discover a vaccine protecting against COVID-19 was met with an international response - during the first five months of 2020 over 120 candidates for vaccines against SARS-CoV-2 were being developed (52) however, by the end of 24 September 2020, the number of candidates exceeded 200, out of which 43 underwent clinical trials (53).

SARS-CoV-2 coronavirus protein S plays an important role in virus entering the host cells and is capable of inducing a response mediated by $\mathrm{T}$ lymphocytes, therefore it has been considered a promising goal to develop a vaccine against SARS-CoV-2 $(54,55)$. Vaccines against SARS-CoV-2 are based on the sequence of mRNA genetic code, corresponding to protein located on the so-called virus spike. After vaccine administration, the immune system produces antibodies and $\mathrm{T}$ lymphocytes specific for that protein.

The types of vaccines developed against SARS-CoV-2 include, among others: subunit, vector,

Table 2. Comparison of selected features of SARS-CoV-2 vaccines thus far approved by the EMA and under rolling review (57).

\begin{tabular}{|c|c|c|c|c|}
\hline Vaccine type - manufacturer & Antigen & Production & Advantages & Defects \\
\hline \begin{tabular}{l}
\multicolumn{1}{c}{ mRNA } \\
$-\quad$ Comirnaty \\
BioNTech, Fosun, \\
Pharma, Pfizer \\
$-\quad$ Moderna (mRNA-1273)- \\
Biotech Spain S.L.
\end{tabular} & Protein S & $\begin{array}{l}\text { Genetically modified } \\
\text { RNA for direct } \\
\text { production of antigen }\end{array}$ & $\begin{array}{l}\text { Easy to design, higher } \\
\text { level of adaptation, } \\
\text { stronger immune } \\
\text { response }\end{array}$ & Highly unstable \\
\hline \begin{tabular}{ll} 
& \multicolumn{1}{c}{ Subunit } \\
- & Novavax* ${ }^{*}$ USA \\
- & Sanofi GSK
\end{tabular} & Protein $\mathrm{S}$ & $\begin{array}{l}\text { Antigen ingredients } \\
\text { are produced as } \\
\text { a whole or a subunit }\end{array}$ & $\begin{array}{l}\text { High security, may } \\
\text { induce a cellular and } \\
\text { humoral immune } \\
\text { response }\end{array}$ & $\begin{array}{c}\text { High costs, lesser } \\
\text { immunogenicity, requires } \\
\text { multiple administration } \\
\text { and adjuvants }\end{array}$ \\
\hline \begin{tabular}{ll} 
& \multicolumn{1}{c}{ Vector } \\
- & Vaxzevria - AstraZeneca \\
- & Johnson\&Johnson - \\
& Janssen Cilag Inter NV
\end{tabular} & Protein S & $\begin{array}{c}\text { Genetically designed } \\
\text { with coded target } \\
\text { gene }\end{array}$ & $\begin{array}{c}\text { Security, strong cellular } \\
\text { and humoral immune } \\
\text { responses }\end{array}$ & $\begin{array}{l}\text { Possible various immune } \\
\text { responses }\end{array}$ \\
\hline
\end{tabular}

*rolling review 


\begin{tabular}{|c|c|c|c|c|c|}
\hline 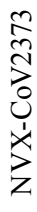 & 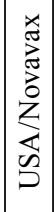 & 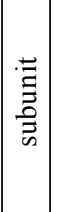 & 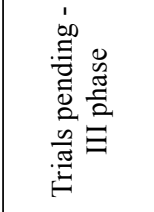 & 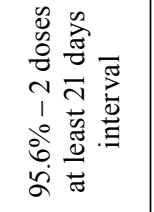 & 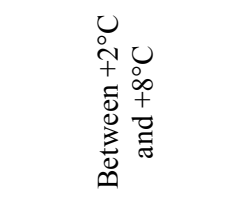 \\
\hline 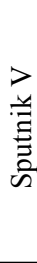 & 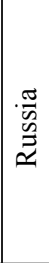 & 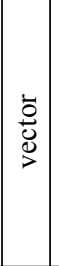 & 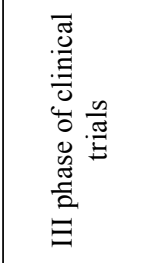 & 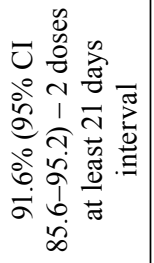 & 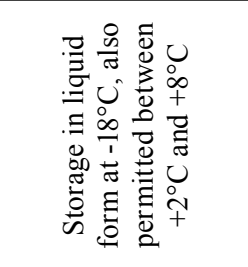 \\
\hline 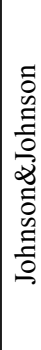 & 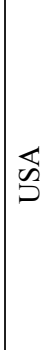 & $\mid$\begin{tabular}{l}
$\tilde{0}$ \\
0 \\
0 \\
\hdashline
\end{tabular} & 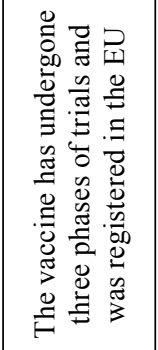 & 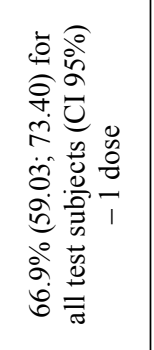 & 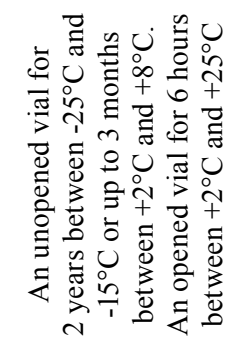 \\
\hline 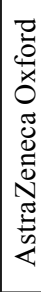 & 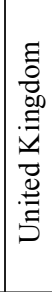 & 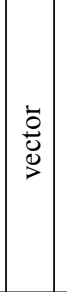 & 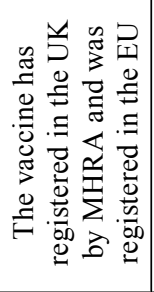 & 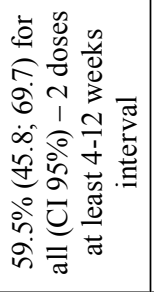 & 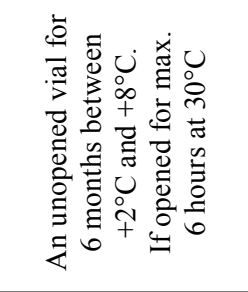 \\
\hline 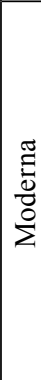 & 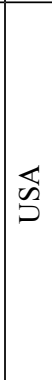 & $\mid \begin{array}{l}\overleftrightarrow{z} \\
\stackrel{\underline{z}}{\Xi}\end{array}$ & 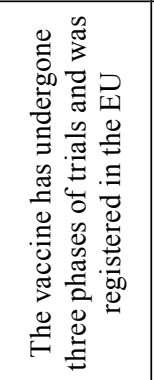 & 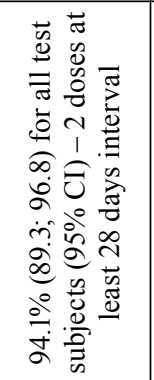 & 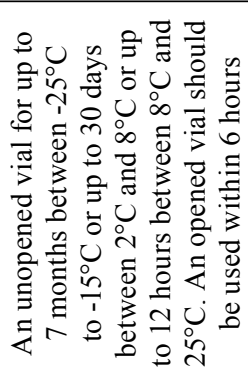 \\
\hline 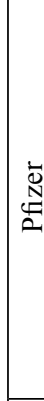 & 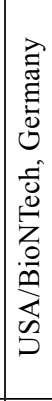 & 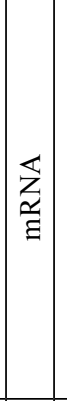 & 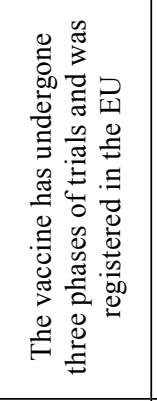 & 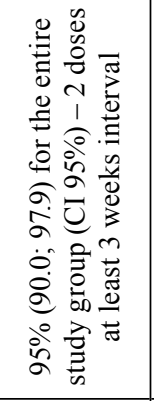 & 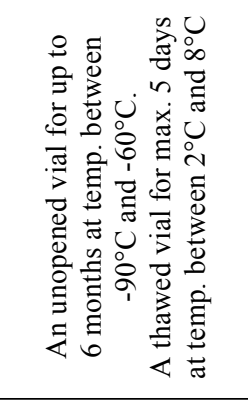 \\
\hline & 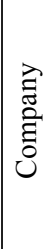 & 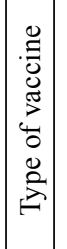 & 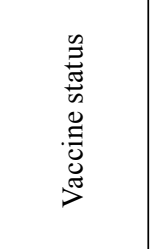 & 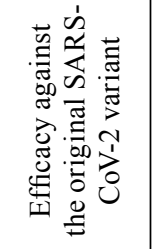 & 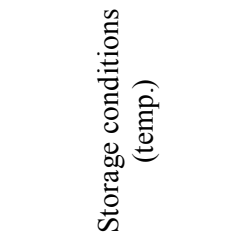 \\
\hline
\end{tabular}

RNA, inactivated, DNA, and live attenuated vaccines. At present no DNA and live attenuated vaccines are administered, some of them are undergoing clinical trials (56). Table 2 shows a comparison of selected features of vaccines thus far approved by the EMA and under rolling review (57).

Efficacious and secure vaccines preventing COVID-19 illness should stimulate the quick response of antibodies (the so-called humoral response) and or T lymphocytes (the so-called cellular response), with simultaneous reduction of undesired adverse side effects, and allow quick implementation especially in case of predictable virus mutations (57). The currently used vaccine types differ by their mechanism and effectiveness.

\section{RNA vaccines}

At the beginning of 1990, it was discovered that direct, intramuscular injection of nucleic acids, both in the form of DNA or RNA in mice, caused in vivo expression of proteins coded by the injected nucleic acid (58). Each protein may be coded and expressed in the form of mRNA which allows the development of preventive and therapeutic vaccines combating different illnesses, such as infections or neoplasms (59).

This discovery allowed the creation of a vaccine requiring a coding sequence for the gene coding the pathogen protein. Over time, the stability of administered nucleic acids, their delivery, and cellular uptake was improved. mRNA-based vaccines are the main hope for solving the pandemic crisis (60). The basic principle of mRNA vaccinations is to supply a transcript coding one or more immunogens to host cell cytoplasm. With transcript's expression, there is created protein located in the membrane, secreted or located inside the cell (61). Vaccines on mRNA platform addressed against SARS-CoV-2 use mRNA modified with nucleosides closed in lipid nanoparticles (mRNALNP) which facilitate embedding into the cell and are addressed against protein $\mathrm{S}$ of the coronavirus spike, or receptor-binding domain (RBD) (62). A typical preparation is composed of an RNA condensing lipid to create a complex with mRNA particles, auxiliary lipids ensuring the rigidity of the structure, and lipid polymer coating modifying surface properties of molecules. After phagocytizing by the cell, mRNA-LNP appears in the environment with low $\mathrm{pH}$ within the endosome, and RNA condensing lipid allows the release of information RNA to the cell's cytosols, therefore it is a key component of this vaccination platform (63). The inclusion of modified nucleosides in 
mRNA sequence with their proper purification may reduce the inflammatory response, therefore vaccines of that type may demonstrate a higher security profile than vaccination platforms based on viruses (62), although it is known that carriers and mRNA condensing lipids may also induce undesired proinflammatory responses (63).

mRNA undergoes temporary expression and does not integrate with the genome therefore they are considered internally secure carriers. Molecularly, mRNA is well known, it does not contain materials of animal origin, and it is synthesized in an efficient, noncellular process of in vitro transcription from DNA templates $(64,65)$ mRNA vaccines are able to induce an immune response, covering both cellular and humoral immunity, and at the same time, they are not subject to the limitation of MHC haplotype (59).

Among the currently used vaccines, the following vaccines are based on mRNA platform: mRNA-1273 by Moderna, BNT162b2 developed by BioNTech/Pfizer (both admitted to trading by FDA and EMA). Those preparations differ in manufacturing technology, method of storage, and efficacy (Table 3).

\section{Vector vaccines}

The research performed since 1980' allowed the use of different viruses as vaccination vectors. Vector vaccines use either replicating but often attenuated, or non-replicating vectors (65). The security range of a vector vaccine increases with the attenuation (75). For this purpose, there are used, among other, adenoviruses, togaviruses, or measles virus. Vector vaccines are based on vectors with a proven high level of security. In host cells, those vaccines allow production, and then release of immunogenic antigens, for some time after the vaccination (76). Viral vectors cause immune reactions and induce antibodies specific for the virus, and $\mathrm{T}$ cells response. One of the advantages of vectors is the ability to multiply the virus to high titers, and relative easiness in introducing antigens coding genes to the vector (77). Some of the viral vectors, such as human adenovirus of the serotype 5 (Ad5) and chimpanzee adenovirus (ChAd), may normally be administered only once, to ensure protection, and are characterized with natural tropism for respiratory tract mucous membrane which, in case of COVID-19, is of great significance.

ChAdOx1 nCoV-19 vaccine, also known as AZD-1222, has been developed by Oxford University (United Kingdom) and AstraZeneca. Due to low seroprevalence in humans for chimpanzee adenovirus $\mathrm{ChAd}$, the vector is characterized by strong immunogenicity, and therefore, high usability in primary vaccination against SARS-CoV-2 (78). In the vaccine, the non-replicant chimpanzee adenovirus contains a sequence coding the antigen of the surface glycoprotein of SARS-CoV-2 (protein S) (79). Vaccination is divided into two separate intramuscular doses, containing no less than $2.5 \mathrm{x}$ 108 infectious units in a dose, whereas the second dose should be administered from 28 to 84 days after the first dose (4-12 weeks) (80). Based on the research performed in the UK, Brazil, and the Republic of South Africa among people aged 18 and above, it was established that the efficacy of the vaccine amounts to $70.4 \%-76 \%$ after two doses, and $64.1 \%$ after at least 1 dose, in protection against symptomatic COVID-19 (80). Pharmaceutical Product Safety Data Sheet informs about the efficacy of 59.5\% (71). The ChAdOx1nCoV-19 vaccine causes a specific response of antibodies after 28 days from administering the first dose in all age groups, including the group of 70 year-olds and older, whereas T lymphocytes response specific for protein $S$ reaches its peak 14 days after the first vaccination (81). Due to the insufficient number of people in the group of 55 year-olds, the efficacy of vaccines among older people, who are most endangered with severe course of COVID-19 cannot be determined with surety (82). Adverse effects often include mild to moderate ones: tenderness $(63.7 \%)$, and pain at the injection site $(54.2 \%)$, the feeling of fatigue $(53.1 \%)$, headache (52.6\%), muscles pain (44\%), and joints pain (26.4\%), feeling unwell (44.2\%), fever $(7.9 \%$, and the feeling of fever $33.6 \%$ ), shivers (31.9\%).

It should be noted that adverse effects vanished within several days and were milder, and less frequently reported after the second dose, in comparison to the first one (71). In II/III phase trials, 13 serious adverse effects occurred (thrombosis) however, they were deemed to have no relation to the vaccine (83). There was reported one instance of transverse myelitis after vaccination with ChAdOx $1 \mathrm{nCoV}-19$ and no death cases resulting from post-vaccination complications (82).

The early 1990' brought the development of adenovirus vectors in gene therapy. Shortly after that, they were also tested as vaccine vectors, and since 2003 they have been used in numerous clinical trials of vaccines (84). The first vaccine to be based on adenovirus vector based on human serotype 26 - Ad26 admitted for trading (1 July 2020) was the vaccine against the Ebola virus. At present, concerning SARS-CoV-2 spreading, attempts are being made to manufacture an effective vaccine based on adenovirus vectors. One of them is the Janssen Ad26.CoV2.S vaccine, also known under the name 
Johnson \& Johnson, which after III phase of clinical trials obtained registration in EU. This vaccine is based on the Ad26 vector in which the expression of protein S of SARS-CoV-2 takes place (71). A singular parenteral administration of Ad26.CoV2.S vaccine ensured protection in the SARS-CoV-2 model in primates other than humans (78). In I/II phase trials it was established that on the 29th day after vaccination the seroconversion ratio for antibodies addressed to protein $\mathrm{S}$ reached in persons aged between 18 and 55 years $99 \%$ with the geometric mean titer of specific antibodies (GMT) amounting to 528 and a dose of $5 \times 1010$ virus particles, $99 \%$ at GMT amounting to 625 and a dose of $1 \times 1011$ virus particles, and respectively among people aged 65 or more $100 \%$ at GMT amounting to 507 and 248. However, it must be considered that the trial included only 15 persons aged 65 or more. The most frequently reported adverse effects of vaccination included pain at the injection site, fatigue, headache, and muscles pain $(84,85)$.

It was demonstrated that non-replicant adenovirus vectors based on human serotype 5 (Ad5) induce immune response both against contagious pathogens and neoplasms in animal models, and cause strong and durable cellular immunity in humans (86). Ad5$\mathrm{nCoV}$ vaccine (CanSino Biologics) includes a nonreplicant Ad5 vector which expresses full-length glycoprotein $\mathrm{S}$ and translocates the gene of the signal peptide of plasminogen activator. A safe dose of the vaccine was determined in the form of 5 x 1010 virus particles, as the dose of 1 x 1011 caused severe undesired reactions in $9 \%$ of the vaccinated (83). The most frequent undesired effects after administering the dose of $5 \times 1010$ virus particles, included pain at the injection site (56\%), fatigue (42\%), fever (32\%), headache (29\%). No severe undesired effects were reported within 28 days after vaccination (87). A single dose of the vaccine caused 4-times increase of antibodies binding with RBD in $94-100 \%$ of the vaccinated and 4-times increase of antibodies binding the virus in $50-75 \%$ of the respondents. Immune response of $\mathrm{T}$ cells reached their peak on 14th, and the antibodies response reached its peak on the 28th day after vaccination (88).

Sputnik V (Gam-COVID-Vac) is another vaccine based on adenovirus vectors, developed by The Nikolai Gamaleya National Center of Epidemiology and Microbiology supervised by the minister of health of Russia. It is composed of two components a recombinant adenovirus vector type $26(\mathrm{rAd} 26)$ and recombinant adenovirus vector type 5 (rAd5) translocating the gene of glycoprotein S. Pursuant to the research, the vaccine-induced strong immune response of $\mathrm{T}$ cells and antibodies in all healthy respondents.
The reported adverse effects were mainly mild, and included, first of all, the pain at the injection site, elevated body temperature, headaches., muscles and joints pain, and weakness (89). Due to the propagation of adenoviruses among humans as the result of natural exposition, some of them may demonstrate resistance to vectors applied. To avoid that, in the development of vaccines, one should choose the serotypes such as Ad26 which, in comparison to Ad5, is more seldom in people and induces a stronger response of T CD8+ cells (90). Also, the selection of chimpanzee adenovirus in the ChAdOx1 nCoV-19 vaccine was aimed to reduce the influence of human adenovirus antibodies on the efficacy of the vaccine (91).

\section{Subunit vaccines}

The development of efficient systems of recombinant protein expressions in 1980' and 1990' contributed to the development of subunit vaccines (92). A subunit vaccine is based on the isolation of genes coding surface proteins of the pathogen, constituting an immunogenic epitope (93). At present, works on over 60 subunit vaccines against SARS-CoV-2 are pending. Among them, vaccine NVX-CoV2373 (Novavax) being in the III phase of clinical trials deserves the most attention. NVX-CoV2373 is based on a recombinant protein vaccine containing Matrix-M adjuvant. The vaccine is administered twice, intramuscularly, at 21 days' intervals (94). The adjuvant demonstrates strong but well-tolerated activity stimulating the translocation of cells presenting the antigen to the site of vaccine injection. This activity strengthens the presentation of antigens within lymphatic glands, and thus propagates the immune response (95). During the trials on primates, it caused high titers of neutralizing antibodies and IgG specific for protein S, and Th1 cells response (96). According to tests, the vaccine is $95.6 \%$ effective against the primary variant of SARS-CoV-2. There are also initial reports of its efficacy towards other variants - British B.1.1.7 (85.6\%) and African B.1.351 (60\%). This vaccine was considered secure. It should be stored at temperatures from $2^{\circ} \mathrm{C}$ to $8^{\circ} \mathrm{C}(95,97,98)$. Other subunit vaccines in the II or III phase of clinical trials include a vaccine against SARS-CoV-2 RBD-dimer by Anhui Zhifei Longcom/Institute of Microbiology, Chinese Academy of Sciences, EpiVacCorona discovered by Vector State Research Centre of Virology and Biotechnology), Sanofi/GSK, and other (94).

\section{Inactivated vaccines}

The history of inactivated vaccines is long. So far, most of the vaccines used, were of this type 
however, due to the time-consuming manufacturing process those vaccines are less useful in preventing COVID-19. The manufacturing technology of inactivated vaccines against COVID-19 is based on the multiplication of SARS-CoV-2 through Vero cellular lineages. The virus is inactivated with the use of $\beta$-propiolactone and then adsorbed with the use of an adjuvant in the form of aluminum hydroxide (97). However, some undesired immune or inflammatory reactions may occur, as associated with incomplete inactivation of the virus used (99). One of the vaccines against SARS-CoV-2 was developed by Wuhan Institute of Biological Products Co., Ltd. In 1st phase trial seroconversion was observed in $100 \%$ of the respondents receiving small and large doses, and in $95.8 \%$ of the respondents receiving intermediate doses, and the geometric mean titer of neutralizing antibodies (GMT) on the 14th day after the third injection of the vaccine, amounted respectively to 316 in the group applying a small dose, 206 with the use of a medium dose, and 297 when the dose was large. Whereas, in the 2nd phase trial with the use of medium doses, GMT amounted to 121, when the vaccine was administered on days 0 and 14 , and 247 after the second dose 21 days after the first injection. This vaccine seems to be more secure than the ones described above - the undesired reactions within 7 days after the injection were reported by $15 \%$ of respondents, and the most frequent were pain at the injection site, and fever (100). Another inactivated vaccine against COVID-19 is PiCoVacc (Beijing-based Sinovac Biotech). In the research, Rhesus macaques were immunized by triple intramuscular injection of a medium $(3 \mu \mathrm{g} / \mathrm{dose})$ or high $(6 \mu \mathrm{g} / \mathrm{dose})$ dose of the vaccine, at 7 days' intervals (day 0,7 , and 14). In the second week after vaccine injecting, the increase of $\mathrm{IgG}$ antibodies specific to protein $\mathrm{S}$ was noted, however, further research is needed to confirm the efficacy and security level of this vaccine (101).

\section{Effects of major SARS-CoV-2 variants on vaccine efficacy}

The appearance of new SARS-CoV-2 variants, other than the one with D614G substitution raises concerns that the vaccines applied so far shall turn out to be less efficient. The B.1.1.7 variant identified in the UK, and the B.1.351 variant identified in the Republic of South Africa, code S proteins with mutations within subunits $\mathrm{S} 1$ and S2. Other variants were also identified in Columbus, Ohio (COH.20G/677H), in Europe (20A.EU2), and domestic mink. According to reports, the antibodies produced (after administering two doses of mRNA vaccine) neutralized the B.1.1.7 variant with titers similar to $\mathrm{D} 614 \mathrm{G}$ virus and neutralized the virus with B.1.351 protein with an average 3-fold decrease of the titer (1: 500), which is assigned to the E484K mutation in RBD. They also maintain protective efficacy towards other variants of SARS-CoV-2 $(102,103)$.

This indicates that the D614G mutation did not increase disease severity or affect the neutralizing activity of vaccine antibodies, suggesting that this variant would not present a threat to vaccine efficacy (104).

Current vaccines primarily target the COVID-19 spike protein based on the prototype Wuhan strain (105). Pfizer-BioNTech's mRNA-based vaccine is one of the developed COVID-19 vaccines.

As demonstrated (106), the Pfizer-BioNTech vaccine is $97 \%$ effective in protecting against a severe form of COVID-19. A study in January/April 2021 showed that $95 \%$ of COVID-19 cases in most European countries and Israel were due to the UK variant (B.1.1.7) of the virus. According to data received from Israel, among 523000 people vaccinated with 2 doses of the vaccine BioNTech/Pfizer (Comirnaty) 544 people (0.1\%) developed COVID-19, out of which 15 people required admittance to the hospital. The condition of 8 patients admitted to the hospital was good, the condition of 3 was moderate, whereas 4 persons were in severe condition.

Randomized, controlled trials with 44 thousand participants showed that administration of BioNTech/ Pfizer vaccine in two doses provides $95 \%$ protection against the coronavirus.

To date, there has been no evidence that the B.1.1.7 variant demonstrates increased clinical severity of illness or immune escape capability $(98,107)$. While the neutralization ability Pfizer/BioNTech BNT162b2 mRNA vaccine immune sera against the B.1.351 (South Africa variant) declined significantly in comparison to that against the B.1.1.7 variant (108).

Wang et al. and Jangra et al. $(107,109)$ indicated that the E484K mutation present in B.1.351 and $\mathrm{P} 1$ variants is affected by the neutralization activity of the Pfizer/ BioNTech vaccine. Gupta R.K. (110) reported a 6-fold decrease in sensitivity of E484K mutant to immune sera from individuals vaccinated with the Pfizer/BioNTech mRNA vaccine and an 11 fold decrease in sensitivity to convalescent sera.

A study published by Baden et al. (66) was conducted on 30,420 volunteers, found a $94.1 \%$ efficacy at preventing COVID-19 after administration of the mRNA-1273 vaccine. Aside from transient local and systemic reactions, no safety concerns were identified.

The mRNA-1273 vaccine has demonstrated $94 \%$ efficacy in phase 3 clinical study (50). The 
neutralization capacity of the mRNA-1273 vaccine against the B.1.1.7 variant was observed, but a decrease in titers of neutralizing antibodies against the P1 and the B.1.351 variants (111).

The Phase 3 ENSEMBLE trial was randomized - a double-blind, placebo-controlled clinical trial designed to evaluate the safety of a single dose of Johnson\&Johnson human adenovirus - vectored vaccine versus placebo in up to 60000 adults (18 years old and older) (112).

Katie Adams (113) reported that Johnson\&Johnson in a single-shot COVID-19 vaccine is effective against B.1.351 (South Africa) and $\mathrm{P} 2$ identified in Brazil. The study also showed no evidence that protection declines over time after administering Johnson\&Johnson (about 3000 participants for 11 weeks and 1000 participants for 15 weeks).

The AstraZeneca vaccine showed only $10 \%$ protection against mild to moderate disease associated with the B.1.351 variant in a young population with a median age of 30 in South Africa (76). According to the results, the AstraZeneca - Oxford vaccine offers more limited protection against the B.1.351 variant than against the B.1.1.7.

The decreased efficacy of the Johnson\&Johnson and AstraZeneca - Oxford vaccines against B.1.351 has already been reported (114).

We have a new outbreak of the pandemic in India. The WHO reported that the Indian B.1.617 variant, dubbed the "double mutant" (a variant of special interest) is spreading more easily than the original virus because it has more than two sequence changes compared to older SARS-CoV-2 variants, and little is known about the virus' ability to evade immunity gained from past infection or vaccines. On 23rd April 2021, there was a report that B.1.617 was neutralized in vitro by sera from people who had either recovered from COVID-19 or received India's Covaxin vaccine (115).

A systematic review including the current evidence related to different variants of SARSCoV-2 and COVID-19 vaccines was conducted through a systemic search utilizing the keywords in the online databases including Scopus, PubMed, and Web of Science; we retrieved all related papers and reports published in English from 2019 to 2021.

\section{Summary}

WHO systematically monitors whether SARS$\mathrm{CoV}-2$ evolves and whether the vaccines protect humans against infections with new variants of the virus. It seems unlikely that the vaccines are ineffective towards the emerging SARS-CoV-2 variants because the antibodies stimulated by the vaccines are polyclonal - addressed against many different fragments of spike protein $\mathrm{S}$ of the virus. However further research must be made indicating how the respective vaccines are dealing with the identified mutations and the whole range of SARS-CoV-2 variants.

\section{Conflict of interest}

The authors report no conflicts of interest.

\section{REFERENCES}

1. Arroyo-Mariolii F., Bullano F., Kucinskas S., Rondon-Moreno C.: PLoS One 16, e0244474 (2021).

2. Pyrć K.: Post. Nauk Med. 4b, 48 (2015) (in Polish).

3. Nowakowska E., Michalak S.S.: Post. Mikrob. 59, 227 (2020) (in Polish).

4. Callaway E.: Nature 585, 174 (2020).

5. https://www.who.int/csr/don/31-december-2020sars-cov2-variants/en/ (accessed on 09.02.2021)

6. Lu R., Zhao X., Lu J., Niu P., Yang B., et al.: Lancet 395, 565 (2020).

7. Baretto N., Jukneliene D., Ratia K., Chen Z., Mesecar A.D., et al.: J. Virol. 79, 15189 (2005).

8. Perlman S., Netland J.: Nat. Rev. Microbiol. 7, 439 (2009).

9. Szuster-Ciesielska A.: Zakażenia 2, 18 (2013) (in Polish).

10. Tang X., Wu C., Li X., Song Y., Yao X., et al.: Natl. Sci. Rev. 17, 1012 (2020).

11. Zang L., Jackson C.B., Mou H., Ojha A., Rangarajan E.S., et al:: Nat. Commun. 11, 9 pages (2020).

12. Holmes K.V., Dominguez S.R.: mBio 4, e 00548 (2013).

13. Mercatelli D., Giorgi F.M.: Front. Microbiol. 11, 13 pages (2020).

14. https://naukaw polsce.pap.pl/aktualnosci/ news $\% 2 \mathrm{C} 85845 \% 2 \mathrm{Cmutacja-wariant-czy-}$ szczep-o-co-chodzi-z-brytyjskim-i-afrykanskimwariantem (accessed on 10.02.2021).

15. Sanjuan R., Domingo-Calap P.: Cell. Mol. Life Sci. 73, 4433 (2016).

16. https://www.medonet.pl/koronawirus/tomusisz-wiedziec, mutacje-koronawirusas a r s - cov-2 - n i e-w plywaja-na-je go zarazliwosc,artykul,54709085.html (accessed on 10.02.2021).

17. https://www.medonet.pl/koronawirus/ koronawirus-w-polsce,mutacje-wirusa-sars-cov-2-pod-lupa-polskich-naukowcow,artykul,65395440. html (accessed on 10.02.2021). 
18. Abdullahi I.N., Emeribe A.U., Ajayi O.A., Oderinde B.S., Amadu D.O., et al.: J. Taibah Univ. Med. Sci. 15, 258 (2020).

19. https://www.acrobiosystems.com/A1226Emerging-mutants-from-SARS-CoV-2-Variants. html (accessed on 10.05.2021).

20. https://www.facebook.com/ECDC.EU/phot os/a.400899079938545/4459446114083801/ (accessed on 10.05.2021).

21. https://www.nytimes.com/interactive/2021/ health/coronavirus-variant-tracker.html (accessed on 10.05.2021).

22. https://www.gisaid.org/ (accessed on 11.02.2021).

23. https://www.cdc.gov/coronavirus/2019-ncov/ more/science-and-research/scientific-briefemerging-variants.html (accessed on 11.02.2021).

24. Forster P., Forster L., Renfrew C., Forster M.: Proc. Natl. Acad. Sci. USA 117, 9241 (2020).

25. Zang L., Jackson C.B., Mou H., Ojha A., Peng H., et al.: Nat. Commun. 11, 6013 (2020).

26. Lauring A.S., Hodcroft E.B.: JAMA 325, 529 (2021).

27. Abramczuk E., Pancer K., Gut W., Litwińska B.: Post. Mikrob. 56, 205 (2017) (in Polish).

28. Lundin A., Dijkman R., Bergstrom T., Kann N., Adamiak B. et al.: PLoS Pathog. 10, e1004166 (2014).

29. Wang N., Shang J., Jiang S., Du L.: Front. Mikrobiol. 11, 298 (2020).

30. Rymer W.: Med. Prakt. 1, 97 (2021) (in Polish).

31. Tegally H., Wilkinson E., Giovanetti M., Iranzadeh A., Fonseca V., et al.: medRxiv 2020, 19 pages (2020).

32. Xie X., Liu Y., Liu J., Zhang X., Zou J.: bioRxiv 2021, 15 pages (2021).

33. https://virological.org/t/preliminary-genomiccharacterisation-of-an-emergent-sars-cov-2lineage-in-the-uk-defined-by-a-novel-set-ofspike-mutations/563 (accessed on 12.02.2021).

34. https://assets.publishing.service.gov.uk/ government/uploads/system/uploads/attachment data/file/959361/Technical_Briefing_VOC2020122_Briefing_2.pdf (accessed on 12.02.2021).

35. https://febs.onlinelibrary.wiley.com/doi/ pdf/10.1111/j.1432-1033.1984.tb07877.x (accessed on 12.02.2021).

36. https://virological.org/t/spike-e484k-mutationin-the-first-sars-cov-2-reinfection-caseconfirmed-in-brazil-2020/584 (accessed on 12.02.2021).

37. Weisblum Y., Schmidt F., Zhang F., DaSilva J., Poston D., et al.: Elife 2020, 31 pages (2020).

38. Larsen H.D., Fonager J., Lomholt F.K., Dalby T., Benedetti G., et al.: Euro Surveill. 26, 2100009 (2021).
39. https://www.who.int/csr/don/06-november2020-mink-associated-sars-cov2-denmark/en/ (accessed on 12.02.2021).

40. https://www.bbc.com/news/worldafrica-55462863 (accessed on 12.02.2021).

41. https://www.gisaid.org/references/gisaid-inthe-news/novel-variant-combination-in-spikereceptor-binding-site/ (accessed on 12.02.2021).

42. https://virological.org/t/genomiccharacterisation-of-an-emergent-sars-cov-2lineage-in-manaus-preliminary-findings/586 (accessed on 12.02.2021).

43. Burki T.: Lancet 397, 462 (2021).

44. https://leknacovid.com/index.php/fakty/38mustacje-sarscov2 (accessed on 10.05.2021).

45. https://www.cdc.gov/coronavirus/2019-ncov/ cases-updates/variant-surveillance/variant-info. html (accessed on 12.05.2021).

46. Jangra S., Ye C., Rathnasinghe R., Stadlbauer D., Personalized Virology Initiative study group; Florian Krammer, et. al.: Lancet Microbe 2, e283 (2021).

47. Tchesnokova V., Kulakesara H., Larson L., Bowers V., Rechkina E., et al.: bioRxiv 2021, 19 pages (2021).

48. Zhang W., Davis B.D., Chen S.S., Martinez J.M.S., Plummer J.T., et al.: JAMA 325, 1324 (2021).

49. van Dorp L., Richard D., Tan C.C.S., Shaw L.P., Acman M., et al.: Nat. Commun. 11, 5986 (2020).

50. Wu K., Werner A.P., Moliva J.I., Koch M., Choi A., et al.: bioRxiv 2021, 20 pages (2021).

51. Li Y.D., Chi W.Y., Su J.H., Ferrall L., Hung C.F., et al.: J. Biomed. Sci. 27, 104 (2020).

52. Jackson L.A., Anderson E.J., Rouphael N.G., Roberts P.C., Makhene M., et al.: N. Engl. J. Med. 12, 383 (2020).

53. Tregoning J.S., Brown E.S., Cheeseman H.M., Flight K.E., Higham S.L., et al.: Clin. Exp. Immunol. 202, 162 (2020).

54. Zhang N.N., Li X.F., Deng Y.Q., Zhao H., Huang Y.J., et al.: Cell 182, 1271 (2020).

55. Zhang Y., Kutateladze T.G.: Nat. Commun. 11, 2920 (2020).

56. https://vac-lshtm.shinyapps.io/ncov_vaccine landscape/ (accessed on 09.02.2021).

57. Chung J.Y., Thone M.N., Kwon Y.J.: Adv. Drug Deliv. Rev. 170, 1 (2021).

58. Wolff J.A., Malone R.W., Williams P., Chong W., Acsadi G., et al.: Science 247, 1465 (1990).

59. Schlake T., Thess A., Fotin-Mleczek M., Kallen K.J.: RNA Biology 9, 1319 (2012).

60. Fuller D.H., Berglund P.: N. Engl. J. Med. 382, 2469 (2020). 
61. Jackson N.A.C., Kester K.E., Casimiro D., Gurunathan S., DeRosa F.: NPJ Vaccines 5, 11 (2020).

62. Laczkó D., Hogan M.J., Toulmin S.A., Hicks P., Lederer K., et al.: Immunity 53, 724 (2020).

63. Wang J., Peng Y., Xu H., Cui Z., Williams R.O.: AAPS PharmSciTech 21, 225 (2020).

64. Sahin U., Kariko K., Tureci O.: Nat. Rev. Drug Discov. 13, 759 (2014).

65. Rauch S., Jasny E., Schmidt K.E., Petsch B.: Front. Immunol. 9, 1963 (2018).

66. Baden L.R., El Sahly H.M., Essink B., Kotloff K., Frey S., et al.: N. Engl. J. Med. 384, 403 (2021).

67. Polack F.P., Thomas S.J., Kitchin N., Absalon J., Gurtman A., et al.: N. Engl. J. Med. 383, 2603 (2020).

68. https://investors.modernatx.com/news-releases/ news-release-details/modernas-covid-19vaccine-candidate-meets-its-primary-efficacy (accessed on 15.03.2021).

69. https://ec.europa.eu/health/documents/ community-register/2020/20201221150522/ anx_150522_pl.pdf (accessed on 15.03.2021).

70. https://www.modernacovid19global.com/eu/pl/ summary-product-characteristics.pdf (accessed on 15.03.2021).

71. https://whc.ifps.org.pl/wp-content/ uploads/2021/02/CHPL-Astrazeneca.pdf (accessed on 17.02.2021).

72. Logunov D.Y., Dolzhikova I.V., Shcheblyakov D.V., Tukhvatulin A.I., Zubkova O.V. et al.: Lancet 397, 671 (2021).

73. https://ec.europa.eu/health/documents/ community-register/2021/20210311151284/ anx 151284 pl.pdf (accessed on 15.03.2021).

74. Shinde V., Bhikha S., Hoosain Z., Archary M., Bhorat Q., et al.: N. Engl. J. Med. 384, 1899 (2021).

75. Draper S., Heeney J.: Nat. Rev. Microbiol. 8, 62 (2010).

76. Enjuanes L., Zuñiga S., Castaño-Rodriguez C., Gutierrez-Alvarez J., Canton J., et al.: Adv. Virus Res. 96, 245 (2016).

77. de Vries R.D., Rimmelzwaan G.F.: Hum. Vaccin. Immunother. 12, 2881 (2016).

78. Jeyanathan M., Afkhami S., Smaill F., Miller M.S., Lichty B.D., et al.: Nat. Rev. Immunol. 20, 615 (2020).

79. Folegatti P.M., Ewer K.J., Aley P.K., Angus B., Becker S., et al.: Lancet 396, 467 (2020).

80. Voysey M., Clemens S.A.C., Madhi S.A., Weckx L.Y., Folegatti P.M., et al.: Lancet 397, 99 (2021).
81. Ramasamy M.N., Minassian A.M., Ewer K.J., Flaxman A.L., Folegatti P.M., et al.: Lancet 396, 1979 (2021).

82. Knoll M.D., Wonodi C.: Lancet 397, 72 (2021).

83. Prüß B.M.: Vaccines (Basel). 9, 30 (2021).

84. Humphreys I.R., Sebastian S.: Immunology 153, 1 (2018).

85. Custers J., Kim D., Leyssen M., Gurwith M., Tomaka F., et al.: Vaccine S0264-410X, 31160 (2020).

86. Colloca S., Barnes E., Folgori A., Ammendola V., Capone S., et al.: Sci. Transl. Med. 4, 115ra2 (2012).

87. Zhu F.C., Guan X.H., Li Y.H., Huang J.Y., Jiang T., et al.: Lancet 396, 479 (2020).

88. Zhu F.C., Li Y.H., Guan X.H., Hou L.H., Wang W.J., et al.: Lancet 395, 1845 (2020).

89. Logunov D.Y., Dolzhikova I.V., Zubkova O.V., Tukhvatulin A.I., Shcheblyakov D.V., et al.: Lancet 396, 887 (2020).

90. Pushparajah D., Jimenez S., Wong S., Alattas H., Nafissi N., et al.: Adv. Drug Deliv. Rev. 170, 113 (2021).

91. Soiza R.L., Scicluna C., Thomson E.C.: Age Ageing 50, 279 (2021).

92. Lundstrom K.: Viruses 12, 1324 (2020).

93. Hansson M., Nygren P.A., Ståhl S.: Biotechnol. Appl. Biochem. 32, 95 (2000).

94. Zhao J., Zhao S., Ou J., Zhang J., Lan W. et al.: Front. Immunol. 11, 602256 (2020).

95. https://www.novavax.com/covid-19coronavirus-vaccine-candidate-updates (accessed on 19.02.2021).

96. Keech C., Albert G., Cho I., Robertson A., Reed P. et al.: N. Engl. J. Med. 383, 2320 (2020).

97. Mahase E.: BMJ 372, n296 (2021).

98. Shen X., Tang H., McDanal C., Wagh K., Fischer W., et al.: Cell Host Microbe 29, 529 (2021).

99. Shen X., Tang H., McDanal C., Wagh K., Fischer W., et al.: bioRxiv 2021, 33 pages (2021).

100.Izda V., Jeffries M.A., Sawalha A.H.: Clin. Immunol. 222, 108634 (2021).

101. Yadav T., Srivastava N., Mishra G., Dharma K., Kumar S., et al.: Hum. Vaccin. Immunother. 16, 2905 (2020).

102. Tada T., Dcosta B.M., Samanovic-Golden M., Herati R.S., Cornelius A., et al.: bioRxiv 2021, 44 pages (2021).

103. Conti P., Caraffa A., Gallenga C.E., Kritas S.K., Frydas I., et al.: J. Biol. Regul. Homeost. Agents 35, 1 (2021).

104. Weissman D., Alameh M.G., de Silva T., Collini P., Hornsby H., et al.: Cell Host Microbe 29, 23 (2021). 
105. Le T.T., Cramer J.P., Chen R., Mayhew S.: Nat. Rev. Drug Discov. 19, 667 (2020).

106. Haas E.J., Angulo F.J., McLaughlin J.M., Anis E., Singer S.R., et al.: Lancet 397, 1819 (2021).

107. Wang P., Casner R.G., Nair M.S., Wang M., Yu J., et al.: bioRxiv 2021, 23 pages (2021).

108. Supasa P., Zhou D., Dejnirattisai W., Liu C., Mentzer A.J., et al.: Cell 184, 2201 (2021).

109. Jangra S., Ye C., Rathnasinghe R., Stadlbauer D., Krammer F., et al.: medRxiv 2021, 14 pages (2021).

110. Gupta R.K.: Nat. Rev. Immunol. 21, 340 (2021).

111. Wu K., Werner A.P., Koch M., Choi A., Narayanan E., et al.: N. Engl. J. Med. 384, 1468 (2021). 112.https://www.janssen.com/johnson-johnsonprepares-resume-phase-3-ensemble-trialits-janssen-covid-19-vaccine-candidate-us (accessed on 10.05.2021).

113. https://www.beckershospitalreview.com/ pharmacy/j-j-vaccine-effective-against-virusvariants-study-shows.html (accessed on 10.05.2021).

114. Bian L., Gao F., Zhang J., He Q., Mao Q., et al.: Expert Rev. Vaccines 20, 365 (2021).

115. https:/www.thehindu.com/sci-tech/health/ covaxin-offers-protection-against-doublemutant-variant-found-in-india-study/ article34429392.ece (accessed on 10.05.2021). 